\title{
Anthós
}

$6-21-2021$

\section{Introduction to 2021 Anthos Dossier}

Rebecca Summer

Portland State University

Follow this and additional works at: https://pdxscholar.library.pdx.edu/anthos

Part of the Education Commons

Let us know how access to this document benefits you.

\section{Recommended Citation}

Summer, Rebecca (2021) "Introduction to 2021 Anthos Dossier," Anthós: Vol. 10: Iss. 1, Article 11. https://doi.org/10.15760/anthos.2021.10.1.11

This open access Article is distributed under the terms of the Creative Commons Attribution-NonCommercialShareAlike 4.0 International License (CC BY-NC-SA 4.0). All documents in PDXScholar should meet accessibility standards. If we can make this document more accessible to you, contact our team. 
The Covid-19 pandemic turned all of our lives upside down in March 2020. Amidst the switch to remote learning, the hectic moves from communal living spaces, the loss of employment, the caring for loved ones, the shock of social isolation, and new vigilance about individual and public health, PSU Honors students showed remarkable resolve to turn this crisis into a learning opportunity. This issue of Anthos provides a glimpse into the ways that students took their research and writing skills to generate new insights about the pandemic as it was ongoing. The papers you'll read provide an incredibly valuable take on the ways the pandemic has changed all aspects of daily life-from dating to engaging with the news; from retaining the right to international education to providing and receiving medical care.

When the Spring 2020 quarter began, we were only a few weeks into the pandemic. I asked the students in my Honors 201: Urban Social Science class to design individual research projects in which they would use qualitative research methods to investigate how the pandemic was changing their lives and the lives of those they knew. In those early few months, we still had much to learn about how Covid-19 operates as a disease, and we were all learning new strategies for coping with such abrupt changes to our personal and professional lives. Student research in this early phase of the pandemic reflected some of the issues most pressing to students at that time of transition: how to maintain social connections and how to most effectively adapt to a new educational reality. Two of the papers in this issue result from these early months. Annabelle R. Winking's paper, "Online Dating Habits amid Covid-19," explores how young adults adapted their dating habits in a period of stay-at-home orders and social distancing. As Winking compellingly argues, forming intimate connections is an essential part of development for young adults. Her research reveals how young adults weighed the risks and benefits of dating during the pandemic. Aakanksha Santosh Rane's paper, "The Impact of COVID-19 on International Students at Portland State University," investigates how international students at PSU navigated early bureaucratic barriers to staying in the United States to continue their education. Rane's research provides critical perspectives from students themselves about the financial and emotional hardships unique to international education during a global pandemic.

By the time I taught HON201: Urban Social Science in the Fall 2020 quarter, most of us had developed some routine-whether sustainable or not-for coping with the pandemic. The research questions that students asked that term reflected the understanding that the pandemic had already changed the way we do things. Research in this middle stage of the pandemic was more reflective about the ways that changes in personal and professional practice might have staying power beyond the life of Covid-19. Particularly salient themes this term were the pandemic's impacts on student mental health and on workplace protocols. In her paper, "A Remote Environment's Effect on the News Consumption of College Students," Amelia R. Webb asks how college students changed their engagement with the news over the course of the pandemic. Her study about news consumption reveals that students learned to balance their exposure to mentally taxing news with their constant access to a 24-hour news cycle on their electronic devices. Webb's study illuminates new pandemic-era skills that college students 
developed in order to stay informed while protecting their mental health. Looking beyond the behaviors and concerns of young adults, Kendra L. Stefan examines pandemic-era rural medical provision in her paper, "Impacts of COVID-19 on Rural Medical Business Models." Her in-depth research on the changing practices of rural healthcare providers offers a vital snapshot of how businesses adapted to financial hardship and fewer customers, and how medical providers changed practices in order to ensure quality healthcare in a time of heightened medical risk. Stefan's insights about what did and did not work for healthcare providers compel readers to consider the ways this professional sphere may change permanently.

The final paper in this issue, "Lessons from the COVID-19 pandemic on the role of socioeconomic status in health outcomes," by Leila Karout, offers a comprehensive review of the ways that socioeconomic status (SES) is a risk factor for Covid-19. This paper did not come out of my HON201: Urban Social Science course but instead is a review article that is an essential contribution to the understanding of inequalities in the suffering from the pandemic. Karout clearly articulates how SES can influence both susceptibility to the disease and its severity. She deftly marshals existing research on Covid-19 outcomes and SES-related health care disparities to call for more research and action on the relationship between SES and Covid-19 health outcomes. This call to the public health community is one we should all heed in order to better understand how to improve equity in preparedness and response to this global pandemic.

These five student perspectives on the diversity of pandemic experiences will surely enhance your own understanding of this ongoing crisis. I hope you enjoy the papers and learn as much from them as I did.

Rebecca Summer

Assistant Professor of Urban Geography

University Honors College, Portland State University

May, 2021 